\title{
ESCRITURAÇÃO FISCAL DIGITAL (EFD): VANTAGENS E DESVANTAGENS A PARTIR DA LITERATURA SELECIONADA
}

\author{
DIGITAL BOOKKEEPING TAX (DBT): ADVANTAGES AND \\ DISADVANTAGES FROM SELECTED LITERATURE
}

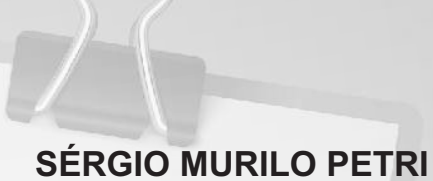

Universidade Federal de Santa Catarina - UFSC (SC)

BÁRBARA HEIDRICH SEIBERT KOETTKER Universidade Federal de Santa Catarina - UFSC (SC)

TATIANE MARQUES DE OLIVEIRA Universidade de Brasília - UNB (DF)

LUANA RAMOS FIGUEIREDO PETRI Universidade Federal de Santa Catarina - UFSC (SC)

MARIA DENIZE HENRIQUE CASAGRANDE Universidade Federal de Santa Catarina - UFSC (SC)

\section{RESUMO}

O objetivo desta pesquisa é revisar a implantação do projeto Sistema Público de Escrituração Digital - SPED, a fim de que se possa identificar e discutir as vantagens e desvantagens da Escrituração Fiscal Digital a partir da literatura selecionada. A pesquisa foi realizada com base em entrevista com funcionário responsável pelo SPED fiscal da Secretaria da Fazenda do Estado de Santa Catarina e a partir da literatura selecionada em uma busca sistemática. Como resultado da pesquisa, destaca-se que: (i) o projeto até então tem se mostrado eficiente ao proposto, como uma aceitabilidade boa dos contribuintes, expandindo gradativamente a excelência; (ii) as vantagens principais abordadas são as melhorias na qualidade da informação, o ganho de produtividade e a eficiência nos processos; (iii) as desvantagens principais são a dificuldade de preparação do pessoal, o custo financeiro e as mudanças na estrutura da empresa; e (iv) dentre as dificuldades pode-se citar o alto custo na implantação de sistemas de informação para a utilização do SPED e a preocupação do correto conhecimento dos contribuintes.Conclui-se que com o SPED-EFD o trabalho intelectual, o conhecimento do contador, sobrepõe-se ao operacional. Exige-se ainda que o profissional tenha visão gerencial, conhecimento em informática, habilidade de aprender e poder de feedback.

Palavras-chave: Sistema Público de Escrituração Digital (SPED). Fisco catarinense. Sistema de informação. Contabilidade tributária. 


\section{ABSTRACT}

The objective of this study is to verify the economic-financial situation of some companies. For that, it is required the joint analysis of their financial statements in order to predict future conditions which will generate results and honor their commitments. This paper aims at estimating discriminant functions for groups of profitable, intermediary and lossmaking companies listed on the BM\&FBOVESPA within 2009 and 2011. The methodological procedures used characterize this study as descriptive, documental and quantitative. The data used were collected from the Economática ${ }^{\circledR}$ database. The companies belonging to the financial sector and services were not considered in the analysis and those which did not show the necessary data were excluded, resulting in a sample of 255 organizations. Data analysis was performed by using the SPSS®software, having as the meeting variable the three groups of companies and as explanatory variables the economic-financial indicators of liquidity, profitability and capital structure. Data analysis identified the existence of separation between groups, pointing to the Debt Breakdown as the variable that best represents this separation. Two functions were created; the first one, which segregated the profitable enterprises from the intermediary ones, showed high ability to demonstrate the differences between the two groups; the second discriminant function accounted for only the residual power for segregation between the intermediary and loss-making companies.

\section{Keywords: Economic and financial indicators. Financial difficulties. Discriminant analysis}

\section{INTRODUÇÃO}

O Sistema Público de Escrituração DigitalSPED faz parte do Programa de Aceleração do Crescimento do Governo Federal (PAC) e tem como objetivo promover a integração dos fiscos, racionalizar e uniformizar as obrigações acessórias para os contribuintes e melhorar a identificação de ilícitos tributários, dentre outros (RECEITA FEDERAL, 2012), e constitui-se em mais um avanço na informatização entre o fisco e os contribuintes. A inovação tecnológica surgiu e está cada vez mais presente no cotidiano, visando à evolução, à praticidade e automação das rotinas dos contadores.

A imagem do profissional contábil foi afetada por muitos escândalos contábeis, como os ocorridos nos Estados Unidos envolvendo diversas empresas, dentre elas a Enron, WorldCom. Além desses fatos, os contadores ainda eram vistos como profissionais que checavam entradas e saídas do patrimônio das empresas. No entanto, essa imagem não combina com 0 atual perfil daquele profissional. Hoje, o seu volume de trabalho aumentou e passou a exigir uma nova postura. Atualmente, aliado da informatização e da globalização, o contador também se tornou ativo, criativo, dinâmico e fundamental para a classe empresarial. De acordo com dados estatísticos do Conselho Federal de Contabilidade, de abril de 2010, chegou-se a um total de 411.613 profissionais, sendo 221.237 contadores (53,75\%) e 190.376 contabilistas (46,25\%).

Já o exercício das funções do poder Executivo é feito por meio da administração direta e indireta. Como exemplo tem-se as Secretarias de Estado das Unidades Federativas. As Secretarias de Estado da Fazenda são órgãos responsáveis pelas finanças do Estado,pela arrecadação de recursos provenientes de tributos estaduais, pela fiscalização dos contribuintes, para garantir que estejam recolhendo o tributo devido, pela distribuição dos recursos entre os diferentes órgãos públicos, de acordo com o orçamento, pelo pagamento de fornecedores do Estado, pela contabilização e controle dos recursos, para que não haja mal uso pelos agentes públicos.

Dessa forma, contadores e fiscais estaduais da fazenda são usuários das informações contábeis e fiscais, geradas pelo SPED.

Portanto, o tema abordado neste trabalho será a revisão da implantação do SPED, juntamente com seus três subprojetos (SPED Contábil, SPED Fiscal e Nota Fiscal Eletrônica) e a discussão dos impactos do SPED Fiscal para a Secretaria da Fazenda do Estado de Santa Catarina.

Nesse contexto, este trabalho tem como problema de pesquisa: Quais as vantagens e desvantagens da implantação do SPED Fiscal a partir da literatura selecionada?

O objetivo destapesquisa é revisar a implantação do projeto Sistema Público de Escrituração Digital - SPED, a fim de que se possa identificar e discutir as vantagens e desvantagens da Escrituração Fiscal Digital a partir da literatura selecionada. 
Para atingir o objetivo geral, os seguintes objetivos específicos serão contemplados: (i) levantar dados recentes em bibliografias e meios eletrônicos do pós-implantação do SPED, fazendo uma breve comparação entre o antes e o depois; (ii) identificar vantagens e desvantagens a partir da literatura em relação à Escrituração Fiscal Digital - EFD e, (iii) investigar dificuldades e ineficiências encontradas no projeto.

Esta pesquisa se justifica pela necessidade de informações que o profissional de contabilidade está enfrentando com a implantação do projeto do Sistema Público de Escrituração Digital e seus subprojetos, SPED Contábil, SPED Fiscal e Nota Fiscal Eletrônica.

Ainda há muita carência no tratamento das legislações vigentes, caracterizando estudos desse gênero como de suma importância.

Nesse caso, a principal contribuição do estudo é a intenção de divulgar o conhecimento sobre a modernização da sistemática atual de cumprimento das obrigações acessórias que envolvem a transparência mútua entre governo e sociedade.

A escolha deste estudo deve-se em parte à atualidade do tema, que não é um assunto estudado ainda em ambiente acadêmico, mas de suma importância para a prática da profissão contábil. 0 profissional adquire experiências próprias em estágios, trabalhos assalariados e em literaturas sobre 0 assunto em questão. Fez-se, necessário buscar tal conhecimento, discuti-lo e expor aos interessados.

Na pesquisa sistematizada para a seleção do referencial teórico dos artigos encontrados sobre 0 assunto SPED e Nota Fiscal Eletrônica não foram localizados trabalhos que tratassem do tema deste estudo. Muitos estudos focalizaram na Nota Fiscal Eletrônica, outros nas expectativas das empresas quanto à implantação e outros ainda, entrevistaram membros da presidência do Conselho Regional de Contabilidade de Santa Catarina (CRC-SC). Nenhuma pesquisa investigou, até o momento, sobre a opinião da implantação do SPED para o Fisco Estadual e nem levantou dados sobre quais foram as novas mudanças já ocorridas após essa implantação, como, por exemplo, a segunda geração da Nota Fiscal Eletrônica. Assim, o presente trabalho se justifica como um estudo original.

A contribuição social do trabalho torna-se evidente, uma vez que as considerações dele resultantes podem servir de base para orientar os usuários da informação do SPED.

Esta pesquisa é formada por quatro seções. Na primeiraseção, apresenta-se a introdução, em que se busca abordar a contextualização sobre o tema de pesquisa. Na segundaseção, apresenta-se a revisão da literatura sobre o Sistema Público de Escrituração Digital. Na terceira seção é apresentada a metodologia da pesquisa. Na quartaseção, apresenta-se a análise e a descrição dos resultados e, na quinta seção, os resultados e as considerações finais. Por fim, elencamse as referências utilizadas na pesquisa.

\section{REFERENCIALTEÓRICO}

Este seção contempla a revisão bibliográfica que fundamenta o desenvolvimento do presente estudo. Primeiramente, apresenta-se a evolução da contabilidade no decorrer dos anos, abordando suas principais mudanças e, posteriormente, enfatiza-se 0 objeto de estudo, a escrituração digital. Dando sequência, abordam-se os três tipos de escriturações da nova legislação, como a escrituração contábil, a escrituração fiscal e a nota fiscal eletrônica. Por último, discorre-se sobre as divergências e similaridades encontradas em pesquisas realizadas.

\subsection{Evolução da Contabilidade e a Tecnologia da Informação}

A contabilidade surgiu quando os homens primitivos, há mais de dois mil anos registravam suas riquezas de diversas formas: utilizando desenhos em pedras, figuras, imagens, com a finalidade de controlar seu rebanho, alimentos e bens. A qualidade dos bens era apresentada na forma de desenhos e as quantidades por meio de riscos, controlando o que já tinham e o que não mais precisavam buscar na natureza. (SILVA, 2003)

Com o objetivo de avaliar os próprios patrimônios e assim controlar suas riquezas, em uma época em que não existiam escritas nem números, procuravam aperfeiçoar-se diante da necessidade de controlar seus bens. Até esse momento, a contabilidade estava centrada e focada somente em controlar o que havia sido conquistado ou adquirido.

A Ciência Contábil evoluiu e Longaray e 
Beuren (2006) abordaram a história em quatro fases: a Contabilidade do Mundo Antigo (em forma de desenhos e riscos), período que vai até 0 ano de 1.200 D.C.; a Contabilidade do Mundo Medieval (em forma manuscrita em cunhas e papiros), período de 1.202 ao ano de 1.494; a Contabilidade do Mundo Moderno (início das publicações), do período de 1.494 ao ano de 1.840; e a Contabilidade do Mundo Contemporâneo (início da informatização), período de 1.840 aos dias de hoje.

Lançamentos de livros diários, emissão de guias, controle de estoques e outros, eram feitos de forma manuscritas, tornando os procedimentos contábeis um grande gasto de tempo para o contador. Ao longo dos anos foi aumentando a quantidade de informações exigidas do profissional, tornando 0 trabalho árduo e problemático.

A descoberta do papiro ocasionou uma grande evolução para a contabilidade, gerando benefícios com avanços da ciência, principalmente da matemática. Nesse período dois momentos fundamentais contribuíram diretamente para a contabilidade: a divulgação do sistema numérico arábico e o aparecimento do método das partidas dobradas introduzindo importantes técnicas matemáticas, pesos, medidas e câmbio. (LONGARAY \& BEUREN, 2006)

De documentos feitos a próprio punho para máquinas de escrever, logo a seguir os computadores, com eles surgiram também diversos sistemas no mercado, os quais informatizaram as práticas contábeis com inúmeras facilidades. Além da agilidade, segurança, confiabilidade e qualidade, há também auxílio aos contadores para a tomada de decisão, como ferramenta de apoio à administração.

Com o crescente aperfeiçoamento da Ciência Contábil, surge a necessidade de um sistema que alcance todas as áreas envolvidas pela contabilidade (contábil, fiscal, tributária, gestão empresarial e demais), e que, assim, facilite e possibilite o uso da contabilidade em sua amplitude.

Atualmente, a administração tributária pública é uma dessas partes envolvidas. Com o auxílio dos sistemas de informações consegue orientar, controlar e fiscalizar micros, pequenas, médias e grandes empresas, analisando as informações do patrimônio, advindas de sistemas de informações contábeis e fiscais.

\subsection{Sistema Público de Escrituração Digital -SPED}

A Contabilidade vem passando por várias mudanças e uma delas é a implantação do Sistema Público de Escrituração Digital, mais conhecido por sua sigla SPED.Começou a ser desenvolvido no Governo do Presidente da República Fernando Henrique Cardoso, em 21 de julho de 2000, pela Lei $n^{\circ} 9.989 / 00$, que institui o Plano Plurianual (PPA 2000-2003), que por sua vez, contemplava o Programa de Modernização das Administrações Tributárias e Aduaneiras, "que visa à implantação de processos apoiados por sistemas de informação integrados, tecnologia da informação e infraestrutura logística". (FRANCISCO, RONCHI \& MECHELN, 2008)

Desde então, uma série de leis, portarias e convênios vêm sendo editadas pelas administrações federais e estaduais, visando suportar as alterações necessárias para que o SPED passe a vigorar efetivamente. (YOUNG, 2009)

A implantação desse sistema faz parte do Programa de Aceleração do Crescimento do Governo Federal implantado pela Receita Federal no ano de 2007, constituindo-se em mais um avanço na informatização da relação entre fisco e contribuinte (SANTOS, 2009) e foi instituído por meio do Decreto $n^{0}$ 6.022, de 22 de janeiro de 2007, publicado no Diário Oficial em edição extra, que definiuo SPED como:

(...) instrumento que unifica as atividades de
recepção, validação, armazenamento e
autenticação de livros e documentos que
integrama escrituração comercial e fiscal dos
empresários e das sociedades empresárias,
mediante fluxo único, computadorizado, de
informações.

A integração das informações e seu compartilhamento têm o objetivo de modernizar a administração pública e reduzir os custos e os entraves burocráticos. Esse processo facilita também 0 cumprimento das obrigações tributárias e fortalece 0 controle e a fiscalização por meio do intercâmbio entre as administrações tributárias. (CLETO e OLIVEIRA, 2010; OLIVEIRAe MAIA, 2008)

O SPED tem como objetivos, dentre outros, promover a integração dos fiscos mediante a padronização e o compartilhamento das informações contábeis e fiscais, respeitando as restrições legais; racionalizar e uniformizar as obrigações acessórias para 
os contribuintes e tornar mais célere a identificação de ilícitos tributários, com a melhoria do controle dos processos, a rapidez no acesso às informações e a fiscalização mais efetiva das operações com 0 cruzamento de dados e auditoria eletrônica. (RECEITA FEDERALDOBRASIL, 2010)

O sistema foi desenvolvido com o intuito de uniformizar e substituir os livros contábeis e fiscais, por processos apoiados em sistemas de informação integrados, tecnologia da informação e infraestrutura logística propiciando a entrega única do que hoje é feito em várias obrigações acessórias e facilitando o trabalho dos profissionais de contabilidade no cumprimento das obrigações acessórias.

Progressivamente o projeto tem a pretensão de abranger todas as empresas do país, considerando que se trata de uma ferramenta criada pelo governo federal com o intuito de inibir ações criminosas contra 0 fisco nacional. Compartilha as informações entre o fisco e os contribuintes, fazendo as empresas gerenciarem suas rotinas de formas mais severas e confiáveis para a tomada de decisão. O SPED é uma iniciativa das administrações tributárias das três esferas de governo em parceria com outras instituições, com a finalidade de estabelecer um novo tipo de relacionamento entre governo e sociedade, baseado na transparência mútua, com reflexos positivos para toda a nação brasileira. (PEREIRAet al, 2008)

Para as empresas atenderem àsregras do SPED, terão que adequar suas atuais estruturas sob todos os aspectos, desde o ambiente físico e as tecnologias necessárias, até a capacitação de seus colaboradores. (SEBOLD, PIONER \& PIONER, 2011) Isso "irá promover um impacto significativo nas empresas, as quais terão que atualizar seus sistemas existentes para atender os layouts definidos pelo SPED". (FARIAet al., 2010)

As escriturações comerciais e fiscais exigidas pelo SPED aos empresários e às sociedades empresárias são os livros diário e os livros razão e seus auxiliares, os livros balancetes, balanços e fichas de lançamentos comprobatórios, para os registros contábeis; registro de entradas e saídas, registro de inventário, registro de apuração do ICMS e IPI, para os registros fiscais.
OSPED iniciou com três grandes subprojetos:

- Escrituração Contábil Digital;

- Escrituração Fiscal Digitale

- Nota Fiscal Eletrônica.

Atualmente, há outros subprojetos já implantados, como a Escrituração Fiscal Digital da Cofins e do PIS/ Pasep (EFD-PIS/COFINS), o Conhecimento de Transporte eletrônico (CT-e) e a Nota Fiscal de Serviços Eletrônica (NFS-e); e também projetos que estão em desenvolvimento, tais como eLalur, Central de Balanços e a Escrituração Fiscal Digital da Folha de Pagamento e das Obrigações Previdenciárias e Trabalhistas (EFD-Social).

\subsubsection{Escrituração Contábil Digital-ECD}

Também conhecida por SPED Contábil, a escrituração contábil digital foi instituída pela Receita Federal do Brasil, por intermédio da Instrução Normativa 787, de 19 de novembro de 2007. Substituirá a atual sistemática de prestação de informação ao fisco e compreenderá a versão digital do livro Diário e do livro Razão e seus auxiliares, do livro Balancetes Diários, Balanços e ficha de lançamento comprobatórios dos assentamentos nele transcritos.

0 critério para o enquadramento da obrigatoriedade é de acordo com o regime tributário de cada empresa. Conforme a instrução normativa da receita federal do Brasil 787/07 (art. $3^{\circ}$ ), estão sujeitas as empresas com acompanhamento econômico-tributário diferenciado e sujeitas à tributação do imposto de renda com base no lucro real a partir de $1^{\circ}$ de janeiro de 2008 . A partir de $1^{\circ}$ de janeiro de 2009 as demais empresas jurídicas sujeitas à tributação do imposto de renda com base no lucro real. Estando facultadas as demais empresas. O prazo fixado pela Receita Federal para a apresentação dos livros é o último dia útil de junho do ano seguinte ao que se refere à escrituração. (PEIXE\& FELSKY, 2009) Portanto, com periodicidade anual.

As empresas devem fazer a validação do arquivo contendo a escrituração, submetendo-a ao Programa Validador e Assinador (PVA) fornecido pelo SPED, assinatura digital do livro pela pessoa que tem 0 poder legitmo, de acordo com os registros da Junta Comercial, e pelo contabilista, que deve gerar e assinar o requerimento para autenticação dirigido à Junta Comercial de sua jurisdição. 
Assinados a escrituração e o requerimento, deve-se fazer a transmissão para o SPED e depois de concluída, será fornecido um recibo. O SPED extrai um resumo e envia para a Junta Comercial competente, que analisará e poderá gerar três situações: autenticação do livro, indeferimento ou sob exigência.

Após a recepção do arquivo pelo SPED, a escrituração vai para um banco de dados, o qual permite que os órgãos parceiros façam consultas e possam extrair várias informações para o trabalho de auditoria.0 PVA tem ainda a funcionalidade de visualizar a escrituração e gerar a recuperação de backup.

Autenticada a escrituração, devem ser adotadas medidas necessárias para evitar a deterioração, extravio ou destruição do livro digital. Ele é composto de dois arquivos principais: o do livro digital e o de autenticação.

A não apresentação da ECD no prazo fixado acarretará a aplicação de multa no valor de $\mathrm{R} \$ 5.000,00$ (cinco mil reais) por mês-calendário ou fração, de acordo com 0 art. 10 da Instrução Normativa da Receita Federal do Brasil $n^{0} 787 / 07$, alterada pela de $n^{\text {a }} 825 / 08$.

As empresas obrigadas ao SPED Contábil e Fiscal estarão dispensadas de apresentar a DIPJ e ainda outras obrigações acessórias, relativas a tributos, como IPI, PIS e COFINS.

\subsubsection{Escrituração Fiscal Digital-EFD}

Também conhecida por SPED Fiscal, foi instituída nacionalmente pelo Convênio de ICMS 143 de 2006. No Estado de Santa Catarina, o Anexo 11 do Regulamento do ICMS/SC trata a partir de seu artigo 24 sobre a EFD. Este substituirá a impressão dos livros de Registro de Entradas, Registro de Saídas, Registro de Inventário e Registro daApuração do ICMS e IPI.

A obrigatoriedade da EFD para as empresas foi definida, inicialmente, de acordo com o faturamento e com sua atividade. A partir de $1^{\circ}$ de janeiro de 2011, a obrigatoriedade foi estendida para os demais contribuintes registrados no Cadastro de Contribuintes do ICMS, exceto os enquadrados no Simples Nacional.

A maneira de se fazer o lançamento contábil fiscal não foi alterada, apenas a forma de declará-lo e arquivá-lo. (MAHLE, 2009) O contador deverá, por meio do PVA, importar o arquivo que contém a escrituração fiscal da empresa, que deve estar de acordo com o Ato
Cotepe/ICMS nº 09/2008. Deverá assiná-lo digitalmente e transmitir para a Secretaria da Fazenda de Jurisdição do estabelecimento. Somente após a confirmação do recebimento, as informações serão repassadas a todas as unidades federadas envolvidas.

As informações que hoje são apresentadas individualmente para vários órgãos estarão em um único banco de dados, o que facilitará a apresentação das obrigações, o que reunidas ocorrerá uma única vez, até - $10^{\circ}$ dia do mês subsequente ao da apuração do imposto.

Para as empresas que transmitirem o arquivo digital, fica dispensada a apresentação da DIME (Declaração do ICMS e do Movimento Econômico) e do SINTEGRA(Sistema Integrado de Informações sobre Operações Interestaduais com Mercadorias e Serviços).

\subsubsection{Nota Fiscal Eletrônica-NF-e}

O sistema de emissão de notas fiscais no Brasil é considerado tradicional e híbrido, por manter o preenchimento destes documentos de forma manual, por sistemas mecanizados (máquinas de escrever) e mais recentemente por sistemas de informações eletrônicos.As notas fiscais tradicionais, em forma de talonário contínuo e suas cópias,deixarão de ser utilizadas e as empresasfarão os registros de suas operações por meio do processamento eletrônico e online de dados. (CLETO, 2006)

Além dos sistemas ultrapassados tecnologicamente que ainda são usados para emissão de notas e mesmo para todos os documentos da área contábil. Nos dias de hoje são altos os custos das administrações tributárias para captar, tratar, armazenar e disponibilizar informações sobre a emissão de notas fiscais dos contribuintes. Os volumes de transações realizadas e a quantia de recursos crescem intensamente, e, na mesma proporção, aumentam os custos para o Estado em detectar e prevenir a evasão tributária. (BISATO e LINKE, 2008)

Um outro problema encontrado no Brasil ainda é a multiplicidade de rotinas de trabalho, burocracia, baixo grau de troca de informações e falta de compatibilidade entre dados econômico-fiscais dos contribuintes, gerados pela autonomia tributária. (BISATO \&LINKE, 2008; FRANCISCO, RONCHI \& MECHELN, 2008; OLIVEIRA \& MAIA, 2008; PEREIRA 
et al., 2008; SANTOS, 2009)

Para mudar essa realidade, surgiu a Nota Fiscal Eletrônica, instituída pelo Anexo 11 da Regulamentação do ICMS, para ser utilizada por contribuintes do ICMS e do IPI, em substituição à Nota Fiscal modelo 1 ou 1-A, a qual estão habituados a visualizar em talões contínuos impressos em gráficas. A NF-e não se destina a substituir os outros modelos de documentos fiscais existentes, como, a modelo 2 ou 0 cupom fiscal. (MARTINS, LUCIANO \& TESTA 2008; OLIVEIRA \& MAIA, 2008; SANTOS, MÜLLER \& CASAGRANDE, 2011; YOUNG, 2009)

O objetivo principal do subprojeto é padronizar o documento fiscal eletrônico no âmbito nacional, com validade jurídica garantida pela assinatura digital do remetente, simplificando as obrigações acessórias dos contribuintes ao mesmo tempo em que permite um controle em tempo real das operações comerciais pelo fisco.

Será um documento exclusivamente digital, emitido antes da ocorrência do fato gerador e armazenado eletronicamente para documentar operações de venda e prestação de serviço ocorridas entre as partes.

No Brasil estima-se que são emitidas mais de 100 milhões de notas fiscais por mês. Dessas, 60 milhões só no Estado de São Paulo. Com esse dado é possível medir o impacto positivo, agilidade e economia que se alcançará nos processos de negócios com a adoção da Nota Fiscal Eletrônica. (YOUNG, 2009)

Num primeiro momento, o subprojeto da NF-e foi implantado em diversas empresas de grande porte, como na Sadia, Souza Cruz, Gerdau, Petrobrás, Kaiser, Ultragaz, Wickbold, Ford, Volkswagen, Telefônica e Eletropaulo. Após isso, além das empresas que aderiram de forma voluntária, seu uso foi expandido às enquadradas na obrigatoridade. Hoje, é obrigatória a todo 0 setor industrial e o de comércio atacadista. (SANTOS, MÜLLER\& CASAGRANDE, 2011) Portanto, a abrangência é para todas as empresas de diversos tamanhos, incluindo as optantes pelo Simples Nacional, salvo as exceções previstas no Protocolo ICMS 42/09, Cláusula primeira, $§ 2^{\circ}$.

Alguns dos principais benefícios para 0 contribuinte são a redução de gastos com papel e impressão e é positivo para o meio ambiente, uma vez que o documento é emitido eletronicamente. Há também a redução de gastos com armazenagem dos documentos fiscais de entrada e saída, redução do tempo de parada de caminhões em postos fiscais e a redução de problemas de escrituração devido a erros de digitação de notas fiscais.

Já os principais benefícios para as administrações tributárias são o aumento da confiabilidade da nota fiscal, a diminuição da sonegação e o aumento da arrecadação do que lhe é devido, a melhoria no processo de controle fiscal, possibilitando um melhor intercâmbio e compartilhamento de informações entre os fiscos, e a redução de custos no processo de controle das notas fiscais capturadas pela fiscalização de mercadorias em trânsito. (RECEITA FEDERALDO BRASIL, 2010)

O Documento Auxiliar da Nota Fiscal Eletrônica (DANFE) não substitui a nota fiscal, porém tem a finalidade de acompanhar a mercadoria da origem até 0 destino. Será emitido em papel comum, em única via, e terá uma chave de acesso para consultas na internet. 0 contribuinte (destinatário) poderá escriturar os dados nele contidos. (MARTINS, LUCIANO \& TESTA, 2008; OLIVEIRA \& MAIA, 2008; SANTOS, MÜLLER \& CASAGRANDE, 2011; YOUNG, 2009)

No entanto, a implantação da NF-e, apresentou algumas dificuldades,como por exemplo,a difusão cultural para a quebra de tradicionais paradigmas, considerada a mais importante. (CLETO, 2006) $O$ autor ainda cita que o desconforto criado é por ser 0 brasileiro um "colecionador de papel por excelência" e a falta de maiores conhecimentos da área da tecnologia acaba gerando o que costuma se chamar de pânico digital.

Outra dificuldade apontada na implantação da NF-e, além da necessidade de investimento, éa necessidade de uma mudança nos processos de negócio, o que não se mostra simples quando posto em prática. (MARTINS, LUCIANO e TESTA, 2008)

Um dos riscos que o projeto da NF-e vem enfrentando é a desoneração do passivo fiscal intangível, pois hoje a empresa não tem certeza se o fornecedor emite a "nota inteira" ou a chamada "meia nota". Isso ocorre quando a empresa: "na ânsia de diminuir os seus custos tributários, ao emitir nota fiscal de bens ou serviços, ao invés de assinalar o valor real da 
operação comercial, o faz apenas pela metade". (FACCI et al., 2005) A empresa que recebe também é conivente e no momento em que a nota é escriturada sabe o valor da nota do fornecedor.

\subsection{Pesquisas Similares}

A seguir, demonstram-se algumas divergências e similaridades encontradas na pesquisa sistematizada realizada para a execução deste trabalho científico:

\section{Quadro 1 - Divergências e Similaridade em Relação aos Artigos Encontrados na Pesquisa Sistematizada}

\begin{tabular}{|c|c|c|c|}
\hline $\begin{array}{l}\text { Autores I } \\
\text { Ano }\end{array}$ & Título & Objetivo do Trabalho & Divergência/Similaridade \\
\hline $\begin{array}{l}\text { Bisato e } \\
\text { Linke(200 } \\
8)\end{array}$ & $\begin{array}{l}\text { Os novos procedimentos contábeis } \\
\text { apresentados pelo Sistema Público } \\
\text { de Escrituração Digital (SPED) }\end{array}$ & $\begin{array}{l}\text { Estudar os novos procedimentos contábeis e } \\
\text { suas expectativas apresentados pelo SPED } \\
\text { com pesquisa junto às empresas participantes } \\
\text { do projeto-piloto. }\end{array}$ & $\begin{array}{l}\text { O artigo aponta os três subprojetos } \\
\text { do SPED aplicando questionários } \\
\text { nas empresas, sendo útil na parte } \\
\text { inicial do referencial teórico. }\end{array}$ \\
\hline $\begin{array}{l}\text { Cleto } \\
(2006)\end{array}$ & $\begin{array}{l}\text { Nota Fiscal Eletrônica (NF-e) - } \\
\text { Revolução digital no meio } \\
\text { empresarial e contábil }\end{array}$ & - & $\begin{array}{l}\text { Não se trata de um artigo científico, } \\
\text { aborda aspectos da implantação da } \\
\text { NF-e e algumas dificuldades } \\
\text { encontradas. }\end{array}$ \\
\hline $\begin{array}{l}\text { Fariaet al. } \\
(2010)\end{array}$ & $\begin{array}{l}\text { SPED - Sistema Público de } \\
\text { Escrituração Digital: Percepção dos } \\
\text { contribuintes em relação aos } \\
\text { impactos da adoção do SPED }\end{array}$ & $\begin{array}{l}\text { Verificar qual a percepção aos impactos da } \\
\text { adoção do SPED, em termos de processos } \\
\text { operacionais e redução de custos em } \\
\text { empresas envolvidas em pelo menos um dos } \\
\text { subprojetos do SPED no Estado de São Paulo. }\end{array}$ & $\begin{array}{l}\text { O artigo expõe o Governo Eletrônico } \\
\text { comparando o Brasil com o Chile. E } \\
\text { aborda a respeito do SPED, dado } \\
\text { uma síntese de todos os } \\
\text { subprojetos. }\end{array}$ \\
\hline $\begin{array}{l}\text { Francisco, } \\
\text { Ronchi e } \\
\text { Mecheln } \\
(2008)\end{array}$ & $\begin{array}{l}\text { Os impactos da implantação do } \\
\text { Sistema Público de Escrituração } \\
\text { Digital (SPED) na gestão das micro e } \\
\text { pequenas empresas }\end{array}$ & $\begin{array}{l}\text { Buscar identificar os possíveis impactos } \\
\text { causados pela implantação do SPED na gestão } \\
\text { das micro e pequenas empresas, relatando } \\
\text { opiniões dos profissionais de contabilidade com } \\
\text { relação ao assunto. }\end{array}$ & $\begin{array}{l}\text { Teorização do SPED completa e de } \\
\text { grande valia. }\end{array}$ \\
\hline $\begin{array}{l}\text { Mahle e } \\
\text { Santana } \\
(2009)\end{array}$ & $\begin{array}{l}\text { Sistema Público de Escrituração } \\
\text { Digital - SPED: um estudo nos } \\
\text { escritórios de contabilidade no } \\
\text { município de Pinhalzinho/SC }\end{array}$ & $\begin{array}{l}\text { Conceituar, definir e interpretar sobre a } \\
\text { legislação vigente e verificar o nível de } \\
\text { percepção para a implantação do SPED nos } \\
\text { escritórios de contabilidade de Pinhalzinho/SC. }\end{array}$ & $\begin{array}{l}\text { Fala sobre os três subprojetos e } \\
\text { caracteriza vantagens e } \\
\text { desvantagens, porém dos escritórios } \\
\text { de contabilidade. Bastante amplo na } \\
\text { parte da Escrituração Fiscal Digital. }\end{array}$ \\
\hline $\begin{array}{l}\text { Martins, } \\
\text { Luciano e } \\
\text { Testa } \\
(2008)\end{array}$ & $\begin{array}{l}\text { Proposta de um framework para } \\
\text { apoio à adoção da nota fiscal } \\
\text { eletrônica }\end{array}$ & $\begin{array}{l}\text { Propor um framework para a adoção da Nota } \\
\text { Fiscal eletrônica, que abranja os mecanismos } \\
\text { componentes e intervenientes dessa adoção. }\end{array}$ & $\begin{array}{l}\text { O artigo trata apenas da NF-e } \\
\text { evidenciando que na implantação } \\
\text { não se trata de um processo simples } \\
\text { quando posto em prática e por meio } \\
\text { dos resultados, traz algumas } \\
\text { vantagens e desvantagens. }\end{array}$ \\
\hline $\begin{array}{l}\text { Oliveira e } \\
\text { Maia } \\
(2008)\end{array}$ & $\begin{array}{l}\text { Nota Fiscal Eletrônica: Projeto } \\
\text { Nacional e a iniciativa municipal de } \\
\text { São Paulo - Uma análise } \\
\text { comparativa }\end{array}$ & $\begin{array}{l}\text { Contextualizar o projeto, procurando promover } \\
\text { o entendimento da NF-e e realizar uma análise } \\
\text { das características de cada um dos modelos } \\
\text { existentes no âmbito Nacional e no Município } \\
\text { de São Paulo. }\end{array}$ & $\begin{array}{l}\text { Centraliza mais na parte da NF-e, } \\
\text { sendo útil na abordagem dos riscos } \\
\text { e desvantagens no questionamento } \\
\text { com o entrevistado. }\end{array}$ \\
\hline $\begin{array}{l}\text { Peixe e } \\
\text { Felsky } \\
\text { (2009) }\end{array}$ & $\begin{array}{l}\text { Compatibilizar as demonstrações } \\
\text { contábeis de acordo com o modelo } \\
\text { governamental - Proposta de } \\
\text { adaptação à Escrituração Contábil } \\
\text { Digital }\end{array}$ & $\begin{array}{l}\text { Analisar a aplicação do sistema da tecnologia } \\
\text { da informação e orientar a adaptação das } \\
\text { atuais demonstrações contábeis ao novo } \\
\text { padrão governamental. }\end{array}$ & $\begin{array}{l}\text { Foca-se no SPED Contábil e na } \\
\text { Certificação Digital. Interessante na } \\
\text { parte da evolução por falar do } \\
\text { contador antes e depois. }\end{array}$ \\
\hline $\begin{array}{l}\text { Pereiraet } \\
\text { al. }(2008)\end{array}$ & $\begin{array}{l}\text { Governança eletrônica na } \\
\text { Administração Pública: Estudo de } \\
\text { caso sobre a Nota Fiscal Eletrônica - } \\
\text { NF-e }\end{array}$ & $\begin{array}{l}\text { Identificar as percepções dos contribuintes } \\
\text { acerca dos benefícios apontados pelo projeto } \\
\text { conceitual da NF-e implantada pelo Governo } \\
\text { do Estado de Rondônia. }\end{array}$ & $\begin{array}{l}\text { Foca-se mais na NF-e, utilizado } \\
\text { casos práticos de lojistas ao emitir as } \\
\text { notas e trazendo os benefícios para } \\
\text { as administrações tributárias. }\end{array}$ \\
\hline $\begin{array}{l}\text { Santos } \\
(2009)\end{array}$ & $\begin{array}{l}\text { SPED - O enfoque na Escrituração } \\
\text { Contábil Digital }\end{array}$ & $\begin{array}{l}\text { Conhecer melhor o conceito do projeto SPED, } \\
\text { e especialmente o SPED Contábil, a sua } \\
\text { definição, a legislação que regula, bem como } \\
\text { os arquivos digitais, o plano de contas } \\
\text { padronizado e a validação desses arquivos } \\
\text { eletrônicos apor meio da certificação digital. }\end{array}$ & $\begin{array}{l}\text { Artigo sintetizado, porém de grande } \\
\text { valia na introdução e na certificação } \\
\text { digital. }\end{array}$ \\
\hline $\begin{array}{l}\text { Santos, } \\
\text { Müller e } \\
\text { Casagran } \\
\text { de }(2011)\end{array}$ & $\begin{array}{l}\text { NF-e - Nota Fiscal Eletrônica: } \\
\text { percepção dos contribuintes } \\
\text { enquadrados na atividade de } \\
\text { comércio atacadista de produtos } \\
\text { alimentícios em geral, estabelecidos } \\
\text { no município de Florianópolis }\end{array}$ & $\begin{array}{l}\text { Investigar a percepção das empresas usuárias } \\
\text { da NF-e, pertencentes à atividade de comércio } \\
\text { atacadista de produtos alimentícios em geral, } \\
\text { estabelecidas no município de Florianópolis. }\end{array}$ & $\begin{array}{l}\text { Aponta bastante a respeito da NF-e, } \\
\text { entrevistando empresas, captando } \\
\text { seus perfis, pontos positivos e } \\
\text { negativos quanto a percepção de } \\
\text { sua implantação. }\end{array}$ \\
\hline $\begin{array}{l}\text { Sebold, } \\
\text { Pionere } \\
\text { Pioner } \\
(2011)\end{array}$ & $\begin{array}{l}\text { Novos rumos na Contabilidade } \\
\text { Pública brasileira: do governo } \\
\text { eletrônico ao Sistema Público de } \\
\text { Escrituração Digital - SPED }\end{array}$ & $\begin{array}{l}\text { Descrever as recentes evoluções da área } \\
\text { contábil brasileira, elencando os benefícios } \\
\text { decorrentes da implantação do SPED para a } \\
\text { Administração Pública brasileira. }\end{array}$ & $\begin{array}{l}\text { Aborda a respeito do governo } \\
\text { eletrônico e seus três atores, e uma } \\
\text { boa síntese do SPED. Aponta } \\
\text { benefícios da Certificação digital } \\
\text { para os contribuintes. }\end{array}$ \\
\hline
\end{tabular}

Fonte: Koettker (2011). 
Nota-se no quadro apresentado que não há semelhança com os objetivos propostos nesse trabalho científico, justificando mais uma vez sua autenticidade e relevância.

Os artigos encontrados ajudaram muito para a elaboração da fundamentação teórica, uma vez que muitos abordavam sobre a conceituação do SPED e seus subprojetos, dando enfoque, principalmente, nas Notas Fiscais Eletrônicas.

No entanto, faz-se necessário a delimitação do escopo da pesquisa para que se torne possível dar uma abordagem científica ao problema em questão. Portanto, esta pesquisa está delimitada a investigar os artigos publicados em anais nos congressos brasileiros de contabilidade - Congresso ANPCONT, Congresso USP de Controladoria e Contabilidade, Congresso Brasileiro de Custos, Encontro da ANPAD, Congresso Brasileiro de Contabilidade e Congresso UFSC de Controladoria e Finanças - dos anos de 2004 a 10/2011, pesquisados pelas palavras chave: SPED, Sistema Público de Escrituração Digital, Escrituração Contábil Digital, Escrituração Fiscal Digital e Nota Fiscal Eletrônica.

$E$, também, em publicações feitas nos periódicos dos conselhos regionais de contabilidade Revista Catarinense da Ciência Contábil (CRC-SC), Revista do CRC-BA, Revista do CRC-PR, Revista do CRC-SP, Revista Mineira de Contabilidade (CRC-MG) e Revista Pensar Contábil (CRC-RJ) - dos anos de 2004 a 10/2011 encontradas em meio eletrônico ou disponíveis na biblioteca do CRC-SC na data de 01/04/2010.

Essa sistematização tem 0 intuito de fazer uma verificação de estudos similares, portanto, foram verificados doze (12) artigos, oito (8) publicados em anais de congressos e quatro (4) em revistas de contabilidade.

\section{METODOLOGIADAPESQUISA}

Metodologia "são os procedimentos e regras utilizadas por determinado método". (RICHARDSON, 1999, p. 22) Já a pesquisa é o "procedimento racional e sistemático que tem como objetivo proporcionar respostas aos problemas que são propostos". (GIL, 1991, p. 19) Portanto, para a elaboração desta pesquisa foram utilizados métodos para encontrar as respostas dos problemas, instrumento indispensável para seu desenvolvimento.

\subsection{Enquadramento Metodológico}

A presente pesquisa tem seu conteúdo baseado não somente em artigos publicados em eventos e periódicos de contabilidade, como também em bibliografias e materiais disponíveis em meio eletrônico, devido à atualidade do assunto.

A metodologia utilizada para atender aos objetivos do presente estudo caracteriza-se como uma pesquisa descritiva com abordagens qualitativas.Descritiva em virtude de desenvolver, esclarecer e analisar ideias, características e conceitos envolvidos na implantação do SPED e seus subprojetos a partir da literatura selecionada, dando ao pesquisador uma maior familiaridade com o problema em estudo.

Já a abordagem qualitativa possibilitar avaliação dos dados individualmente, em procedimentos de interpretação de cunho racional e intuitivo, capazes de contribuir para a melhor compreensão e entendimento, porém sem levar em conta a sua quantidade e nem fazer uma relação entre as variáveis, empregando instrumentos estatísticos.

Quanto aos procedimentos de coleta de dados, a pesquisa enquadra-se como primária e secundária. Isto se dá pela entrevista com o funcionário responsável pelo SPED Fiscal na Secretaria da Fazenda do Estado de Santa Catarina (dados primários) e por utilizar obras bibliográficas, publicações e legislação do tema pesquisado (dados secundários).

\subsection{Procedimentos para Revisão do Referencial Teórico}

A revisão do referencial teórico abordado neste estudo foi estruturada de forma a desenvolver o assunto e seus conceitos mais genéricos para assuntos mais específicos, tentando manter uma linguagem clara para todos os tipos de interessados.

Foram utilizadas para a apresentação das principais ideias e abordagens artigos publicados em anais nos congressos de contabilidade nacionais, como - Congresso ANPCONT, Congresso USP de Controladoria e Contabilidade, Congresso Brasileiro de Custos, Encontro da ANPAD, Congresso Brasileiro de Contabilidade e Congresso UFSC de Controladoria e Finanças \& Iniciação Científica em Contabilidade - dos 
anos de 2004 a outubro de 2011. Também foram buscados artigos em publicações feitas nos periódicos dos conselhos regionais de contabilidade, como a Revista Catarinense da Ciência Contábil (CRC-SC), Revista do CRC-BA, Revista do CRC-PR, Revista do CRC-SP, Revista Mineira de Contabilidade (CRC-MG) e Revista Pensar Contábil (CRC-RJ) - dos anos de 2004 a outubro de 2011, encontradas em meio eletrônico ou disponíveis na biblioteca do CRC-SC na data de 01/04/2010. Como também em legislações vigentes e no livro de Lúcia Helena Briski Young, SPED: Sistema Público de Escrituração Digital da editora Juruá do ano de 2009. Esse livro foi utilizado por tratar de um tema recente e com pouca literatura publicada, comentando e demonstrando como executar corretamente a implantação do SPED. Portanto, foi utilizado esse livro como referência para a conceituação.

\subsection{Procedimento para Coleta e Análise de Dados}

A coleta dos dados foi realizada por meio de entrevista do pesquisador com o pesquisado, a fim de obter os dados, as informações e as opiniões acerca do assunto de estudo, permitindo ao pesquisador retirar de sua entrevista elementos de reflexão e análise para a elaboração dos resultados e para responder a seus objetivos específicos.

A entrevista foi realizada com o coordenador e responsável pela Escrituração Fiscal Digital na Secretaria da Fazenda do Estado de Santa Catarina, em 04 de maio de 2010, no período vespertino, em torno das 16 horas às 17 horas. Foram, mantidos contatos iniciais por meio do endereço eletrônico spedfiscal@sefaz.sc.gov.br, disponibilizado no site próprio da SEF, para o agendamento da entrevista.

A entrevista foi de forma estruturada com tratamentos qualitativos, realizando-se um roteiro com itens a serem falados durante a conversação. As respostas foram colhidas em um aparelho gravador e transcritas.A transcrição não seráapresentada neste trabalho a pedido do entrevistado.

\section{APRESENTAÇÃO E ANÁLISE DOS RESULTADOS}

Em resposta ao primeiro objetivo específico de levantar dados bibliográficos recentes do pósimplantação do SPED, fazendo uma breve comparação entre 0 antes e o depois, encontrou-se três autores relevantes, que publicaram em meio eletrônico sobre a segunda geração da nota fiscal eletrônica. São eles, Duarte (2009), Borges (2009) e Bahia (2009).

Esses autores citados abordam que na primeira fase da nota fiscal eletrônica foram discriminados produtos, valores e impostos para fornecer a autorização legal em arquivo eletrônico, e que agora a ideia é documentar todos os eventos que ocorrem durante o ciclo de vida do documento fiscal, como exemplos de série de eventos que serão acompanhados nessa nova fase da NF-e:
a) Registro de saída do produto à confirmação do recebimento da mercadoria;
b) Registro de roubo de carga;
c) Carta de correção;
d) Confirmação de exportação pela aduana;
e) Confirmação de emplacamento de veículos pelo DETRAN;
f) Registro de devolução de mercadoria;
g) Rastreamento do fluxo fisco nos postos fiscais de divisa e SUFRAMA;
h) E outras ocorrências.

Uma das mudanças nessa nova fase é a implementação do Ministério da Ciência e Tecnologia, que reservou $\mathrm{R} \$ 30$ milhões de reais no projeto para que as empresas possam saber onde está o produto enviado a algum cliente, por meio do rastreamento de etiquetas RFID (identificação via radiofrequência). Vai integrar as etiquetas à nota que acompanha cada produto, a DANFE, permitindo um maior controle e redução de simulação de operações interestaduais para o fisco.

O RFID deve entrar como parte integrante do plano de otimização dos registros de Danfes nos postos de fiscalizações, com o fim de agilizar esse processo e diminuir as chances de fraude. Já para o Estado, o objetivo é melhorar controles, recolher a arrecadação de tributos que lhe devido e promover a concorrência leal entre as empresas.

Portanto, essa segunda geração resulta da evolução do modelo. Tem a pretensão de atingir todos os contribuintes e ampliar a transparência das transações, 
impedindo o artifício de emitir a nota fiscal para uma localidade com menor alíquota de imposto e de lá simular o envio da mercadoria a um novo destino.

As primeiras notas foram emitidas a partir de setembro de 2006. Atualmente o Brasil já possui um totalde 1.140.456.357 notas fiscais eletrônicas autorizadas, não considerando as canceladas ou denegadas,gerando um total de $\mathrm{R} \$ 33,7$ trilhões de reais, de acordo com o portal da Nota Fiscal Eletrônica na data de 01/07/2010.

Diante desses números relevantes de notas fiscais autorizadas desde 2006 até a data atual (10/2011), um curto espaço de tempo, e do notável avanço gradativo do projeto, amplia-se sua abrangência e aperfeiçoamento a cada dia. Pode-se dizer que 0 projeto até então tem se mostrado eficiente ao proposto, com uma aceitabilidade boa dos contribuintes.

Em resposta ao segundo objetivo específico, o de identificar vantagens e desvantagens na opinião do fisco catarinense em relação à EFD, fez-se entrevista com o responsável pela área fiscal da Secretaria da Fazenda do Estado de Santa Catarina. As desvantagens apontadas seriam o desconhecimento de alguns contabilistas na escrituração de lançamentos a débitos e a créditos, o que acaba ocasionando erros nos lançamentos, como a não utilização do código correto do plano de contas. Muitas vezes é usando o código genérico sem fazer a descrição adequada, por ser mais fácil e cômodo. Esse código genérico só poderia ser utilizado se não houvesse a conta específica do lançamento e com sua devida descrição. Issa atitude poderia ser passível de punições, uma vez que a Secretaria da Fazenda, órgão fiscalizador, julgaria incorreta a informação enviada.

Entre as vantagens apontadas pelo responsável pela EFD tem-se o reconhecimento de alguns contadores pela facilitação que o surgimento do SPED ocasionou nas rotinas da organização. Outra vantagem destacada é a disponibilidade dos livros fiscais das empresas aos servidores da Secretaria da Fazenda para consultas rápidas ou para uma auditoria eletrônica, facilitando o trabalho também desses servidores, permitindo, assim, que as Administrações Fazendárias minimizem o tempo e os recursos despendidos com processos fiscalizatórios.

Destacou o entrevistado que no decorrer do tempo o projeto e os métodos de controle estão sendo ampliados e que a tendência é a diminuição da sonegação fiscal, fato considerado benéfico para todo o sistema tributário brasileiro.

Em resposta ao terceiro objetivo específico, de investigar dificuldades e ineficiências encontradas no projeto, encontraram-se aspectos de risco para o projeto da nota fiscal eletrônica, o qual, vem enfrentando a desoneração do passivo fiscal intangível. Hoje a empresa não tem certeza se o fornecedor emite a nota inteira ou meia nota. Isso ocorre, conforme já mencionado quando a empresa, "na ânsia de diminuir os seus custos tributários, ao emitir Nota Fiscal de bens ou serviços, ao invés de assinalar o valor real da operação comercial, o faz apenas a metade". (FACClet al., 2005) A empresa que recebe também é conivente e no momento que a nota é escriturada sabe o valor da nota do fornecedor.

Pesquisa recente apresentada pelo telejornal da Rede Globo, Jornal Nacional (2011) mostrou:

[..] que o Brasil é bicampeão na burocracia dos impostos para as empresas. Essa pesquisa avalia três pontos principais: 0 custo de todos os impostos e contribuições, 0 número de vezes que são recolhidos no ano e o tempo para dar conta de tudo. As empresas brasileiras gastam $\mathrm{R} \$ 43$ bilhões por ano só para manter funcionários e equipamentos para atender a burocracia dos impostos. Por estas razões o contador tem sido cada vez mais valorizado pelo árduo trabalho a ser exercido dentro das organizações. Juntamente, o sistema de arrecadação tributária e a geração de informações gerenciais tem evoluído, como o SPED, tentando facilitar a vida do contribuinte e dos órgãos fiscalizadores. Porém, este pódio não é positivo, pois só nos mostra o quanto temos ainda para evoluir nos controles dos processos e nos objetivos firmados na criação do SPED, que seria em resumo: racionalizar, modernizar e facilitar.

No Quadro 2 são apresentadas as contribuições e as dificuldades da pesquisa em um comparativo com as publicações de artigos encontrados na busca sistematizada, bem como as respostas colhidas em entrevista com o servidor responsável pela implantação do SPED na Secretaria do Estado da Fazenda de Santa Catarina. 


\section{Quadro 2 - Contribuições e Dificuldades da Pesquisa}

\begin{tabular}{|c|c|c|c|}
\hline $\begin{array}{l}\text { Autores I } \\
\text { Ano }\end{array}$ & Título & Divergência/Similaridade & $\begin{array}{l}\text { Contribuições ou dificuldades da } \\
\text { pesquisa realizada }\end{array}$ \\
\hline $\begin{array}{l}\text { Bisato e } \\
\text { Linke }(200 \\
8)\end{array}$ & $\begin{array}{l}\text { Os novos procedimentos contábeis } \\
\text { apresentados pelo Sistema Público } \\
\text { de Escrituração Digital (SPED) }\end{array}$ & $\begin{array}{l}\text { O artigo aponta os três subprojetos } \\
\text { do SPED aplicando questionários } \\
\text { nas empresas, sendo útil na parte } \\
\text { inicial do referencial teórico. }\end{array}$ & $\begin{array}{l}\text { Maiores barreiras para o contribuinte é a } \\
\text { insegurança, para o Fisco é a rejeição por } \\
\text { parte dos contribuintes e para o profissional } \\
\text { contábil é o investimentos em Infraestrutura. }\end{array}$ \\
\hline $\begin{array}{l}\text { Cleto } \\
(2006)\end{array}$ & $\begin{array}{l}\text { Nota Fiscal Eletrônica (NF-e) - } \\
\text { Revolução digital no meio } \\
\text { empresarial e contábil }\end{array}$ & $\begin{array}{l}\text { Não se trata de um artigo científico, } \\
\text { aborda aspectos da implantação da } \\
\text { NF-e e algumas dificuldades } \\
\text { encontradas. }\end{array}$ & $\begin{array}{l}\text { Burocracia no atual modelo tributário } \\
\text { havendo perda de tempo. E dificuldades nas } \\
\text { mudanças de tradicionais paradigmas, como } \\
\text { acumular papéis. }\end{array}$ \\
\hline $\begin{array}{l}\text { Fariaet al. } \\
(2010)\end{array}$ & $\begin{array}{l}\text { SPED - Sistema Público de } \\
\text { Escrituração Digital: Percepção dos } \\
\text { contribuintes em relação aos } \\
\text { impactos da adoção do SPED }\end{array}$ & $\begin{array}{l}\text { O artigo expõe o Governo Eletrônico } \\
\text { comparando o Brasil com o Chile. E } \\
\text { aborda a respeito do SPED, dado } \\
\text { uma síntese de todos os } \\
\text { subprojetos. }\end{array}$ & $\begin{array}{l}\text { Não reduziu de tempo de emissão da NF-e, } \\
\text { não aumentou a agilidade e produtividade no } \\
\text { recebimento e não reduziu na aquisição de } \\
\text { papéis. Redução de custo razoável. } \\
\text { Benefícios no futuro. }\end{array}$ \\
\hline $\begin{array}{l}\text { Francisco, } \\
\text { Ronchi e } \\
\text { Mecheln } \\
(2008)\end{array}$ & $\begin{array}{l}\text { Os impactos da implantação do } \\
\text { Sistema Público de Escrituração } \\
\text { Digital (SPED) na gestão das micro e } \\
\text { pequenas empresas }\end{array}$ & $\begin{array}{l}\text { Teorização do SPED completa e de } \\
\text { grande valia. }\end{array}$ & $\begin{array}{l}\text { Custo alto para contratação de profissional } \\
\text { especializado e implantação de Software em } \\
\text { empresas de poucas movimentações. } \\
\text { Fechamento de muitas micros e pequenas } \\
\text { empresas por falta de adequação. }\end{array}$ \\
\hline $\begin{array}{l}\text { Mahle e } \\
\text { Santana } \\
(2009)\end{array}$ & $\begin{array}{l}\text { Sistema Público de Escrituração } \\
\text { Digital - SPED: um estudo nos } \\
\text { escritórios de contabilidade no } \\
\text { município de Pinhalzinho/SC }\end{array}$ & $\begin{array}{l}\text { Fala sobre os três subprojetos e } \\
\text { caracteriza vantagens e } \\
\text { desvantagens, porém dos escritórios } \\
\text { de contabilidade. Bastante amplo na } \\
\text { parte da Escrituração Fiscal Digital. }\end{array}$ & $\begin{array}{l}\text { Contadores dos escritórios desacreditados no } \\
\text { preparo dos clientes para o SPED e sugerem } \\
\text { mais treinamentos e cursos para sua } \\
\text { preparação. }\end{array}$ \\
\hline $\begin{array}{l}\text { Martins, } \\
\text { Luciano e } \\
\text { Testa } \\
(2008)\end{array}$ & $\begin{array}{l}\text { Proposta de um framework para } \\
\text { apoio à adoção da nota fiscal } \\
\text { eletrônica }\end{array}$ & $\begin{array}{l}\text { O artigo trata apenas da NF-e } \\
\text { evidenciando que na implantação } \\
\text { não se trata de um processo simples } \\
\text { quando posto em prática e por meio } \\
\text { dos resultados, traz algumas } \\
\text { vantagens e desvantagens. }\end{array}$ & $\begin{array}{l}\text { Dificuldades na integração e mudanças de } \\
\text { processos internos da empresa, como } \\
\text { adaptar os sistemas de gestão de TI às suas } \\
\text { necessidades. Dificuldades culturais e } \\
\text { investimentos altos. }\end{array}$ \\
\hline $\begin{array}{l}\text { Oliveira e } \\
\text { Maia } \\
(2008)\end{array}$ & $\begin{array}{l}\text { Nota Fiscal Eletrônica: Projeto } \\
\text { Nacional e a iniciativa municipal de } \\
\text { São Paulo - Uma análise } \\
\text { comparativa }\end{array}$ & $\begin{array}{l}\text { Centraliza mais na parte da NF-e, } \\
\text { sendo útil na abordagem dos riscos } \\
\text { e desvantagens no questionamento } \\
\text { com o entrevistado. }\end{array}$ & $\begin{array}{l}\text { Custo/Investimento Inicial grande; Guerra } \\
\text { Fiscal entre Estados aumentada; Outras } \\
\text { janelas de sonegação; Volume grande de } \\
\text { informações para auditorias fiscais; Número } \\
\text { reduzido de Peritos especializados. } \\
\end{array}$ \\
\hline $\begin{array}{l}\text { Peixe e } \\
\text { Felsky } \\
(2009)\end{array}$ & $\begin{array}{l}\text { Compatibilizar as demonstrações } \\
\text { contábeis de acordo com o modelo } \\
\text { governamental - Proposta de } \\
\text { adaptação à Escrituração Contábil } \\
\text { Digital }\end{array}$ & $\begin{array}{l}\text { Foca-se no SPED Contábil e na } \\
\text { Certificação Digital. Interessante na } \\
\text { parte da evolução por falar do } \\
\text { contador antes e depois. }\end{array}$ & $\begin{array}{l}\text { Aponta aprofundamento maior nos } \\
\text { subprojetos à medida que vai expandindo e } \\
\text { sendo adaptado. E que aumente a } \\
\text { transparência dos órgãos de tributação, } \\
\text { arrecadação e fiscalização. }\end{array}$ \\
\hline $\begin{array}{l}\text { Pereiraet } \\
\text { al. }(2008)\end{array}$ & $\begin{array}{l}\text { Governança eletrônica na } \\
\text { Administração Pública: Estudo de } \\
\text { caso sobre a Nota Fiscal Eletrônica - } \\
\text { NF-e }\end{array}$ & $\begin{array}{l}\text { Foca-se mais na NF-e, utilizado } \\
\text { casos práticos de lojistas ao emitir as } \\
\text { notas e trazendo os benefícios para } \\
\text { as administrações tributárias. }\end{array}$ & $\begin{array}{l}\text { Benefícios de diminuição de custos apenas } \\
\text { virão no futuro. Desemprego com a } \\
\text { automação dos processos. Falhas de } \\
\text { comunicação no suporte. }\end{array}$ \\
\hline $\begin{array}{l}\text { Santos } \\
(2009)\end{array}$ & $\begin{array}{l}\text { SPED - O enfoque na Escrituração } \\
\text { Contábil Digital }\end{array}$ & $\begin{array}{l}\text { Artigo sintetizado, porém de grande } \\
\text { valia na introdução e na certificação } \\
\text { digital. }\end{array}$ & $\begin{array}{l}\text { Esta tecnologia deve ser usada com } \\
\text { responsabilidade, permitindo uma relação } \\
\text { mais transparente entre fisco e contribuinte. }\end{array}$ \\
\hline $\begin{array}{l}\text { Santos, } \\
\text { Müller e } \\
\text { Casagran } \\
\text { de }(2011)\end{array}$ & $\begin{array}{l}\text { NF-e - Nota Fiscal Eletrônica: } \\
\text { percepção dos contribuintes } \\
\text { enquadrados na atividade de } \\
\text { comércio atacadista de produtos } \\
\text { alimentícios em geral, estabelecidos } \\
\text { no município de Florianópolis }\end{array}$ & $\begin{array}{l}\text { Aponta bastante a respeito da NF-e, } \\
\text { entrevistando empresas, captando } \\
\text { seus perfis, pontos positivos e } \\
\text { negativos quanto a percepção de } \\
\text { sua implantação. }\end{array}$ & $\begin{array}{l}\text { Mudanças na estrutura da empresa após a } \\
\text { implantação da NF-e e agilidade na } \\
\text { realização das operações. Resultados } \\
\text { satisfatórios em termos de redução de custos } \\
\text { de impressão e aquisição de papel. }\end{array}$ \\
\hline $\begin{array}{l}\text { Sebold, } \\
\text { Pionere } \\
\text { Pioner } \\
(2011)\end{array}$ & $\begin{array}{l}\text { Novos rumos na Contabilidade } \\
\text { Pública brasileira: do governo } \\
\text { eletrônico ao Sistema Público de } \\
\text { Escrituração Digital - SPED }\end{array}$ & $\begin{array}{l}\text { Aborda a respeito do governo } \\
\text { eletrônico e seus três atores, e uma } \\
\text { boa síntese do SPED. Aponta } \\
\text { benefícios da Certificação digital } \\
\text { para os contribuintes. }\end{array}$ & $\begin{array}{l}\text { A Administração Tributária possui alto grau de } \\
\text { descentralização fiscal, devendo ser mais } \\
\text { efetiva e eficiente nos controles, porém, } \\
\text { ainda em transição a contabilidade com a } \\
\text { vinda do SPED. }\end{array}$ \\
\hline
\end{tabular}

Fonte: Adaptado de Koettker (2011). 
Martins, Luciano e Testa (2008) mostram em sua pesquisa uma postura paralela à do responsável pela EFD da Secretaria da Fazenda, uma vez que esse diz participar de e reuniões com a SEFAZ e FISCO para buscar o padrão esperado pelo projeto SPED, que se torna contraditório, uma vez que legislação e as normas vigentes deveriam ser autoexplicativas e claras, não devendo deixar dúvidas aos contribuintes. Porém, a SEFAZ se mostra aberta a esclarecer dúvidas, uma vez que prefere respondê-las a haver dados incorretos em suas informações, principalmente no início do projeto quando aconteciam muitos questionamentos sobre 0 funcionamento correto do sistema.

Na pesquisa de Bisato e Linke (2008), os autores mostram que a maior barreira apontada na aplicação do questionário por parte do Fisco é a preocupação com a aceitabilidade dos contribuintes. Essa indagação não surgiu nesta pesquisa, uma vez que o projeto já está bem encaminhado e aceito pelos contribuintes. Outras barreiras apontadas são a dificuldade de adaptação e a falta de conhecimento e informação. Esta segunda, sim, é uma preocupação ainda pertinente pelos fiscais para a correta escrituração dos processos.

O estudo de Pereira et al. (2008) aponta que a Unidade Fazendária do Estado de Rondônia não está dando esclarecimentos devidos a alguns aspectos importantes do projeto, ocasionando falhas de entendimento, contradizendo, a fala da SEFAZ e da Receita Federal, a qual diz dar suporte aos seus projetos. No entanto, vale destacar que não são todas as SEFAZ que não atendem aos seus usuários, uma vez que o Estado de Santa Catarina fornece suporte tentando esclarecer ao máximo as dúvidas dos contribuintes.

Numa indagação nova na pesquisa de Oliveira e Maia (2008), os autores abordam a respeito de novos crimes tributários que irão surgir com a informatização dos processos e que os criminosos cibernéticos irão conseguir maneiras inovadoras para burlar a administração pública, diminuindo o ônus tributário das empresas, ressaltando a insegurança dos contribuintes quanto à confiabilidade do sistema. Entretanto, mudanças sempre são lentas e se espera que sejam positivas. Pode-se analisar que o projeto SPED tem se tornado um processo muito mais confiável que 0 anterior, que era feito em papéis. Portanto, espera-se e deve-se confiar que se torne um projeto de sucesso.

Conclui-se, portanto, que as dificuldades apontadas nesta pesquisa são diversas. Algumas são mais constantes, como o alto custo na implantação de sistemas de informação para a utilização do SPED e a preocupação do correto conhecimento dos contribuintes para a escrituração fidedigna e padronizada exigida pelos órgãos fiscalizadores.

\section{CONSIDERAÇÕES FINAIS}

O projeto do SPED, implantado nas empresas, tem representado grande sucesso e cumprido seus objetivos, porém, como toda mudança inovadora, é um processo gradativo de avanços a serem percorridos até a sua excelência.

Nota-se com a primeira e logo após a segunda geração da Nota Fiscal Eletrônica que o projeto tem se expandido, tornando obrigatória para um maior número de empresas. A quantidade de notas fiscais emitidas está na casa dos bilhões, crescem a cada segundo e os sistemas de informação têm sofrido avanços para atender melhor o contribuinte e a administração tributária, entre outros.

A realização deste estudo deve-se à importância do projeto SPED na relação contribuinte, contabilidade e fisco. Apesar do elevado número de empresas obrigadas a utilizarem o SPED, ainda encontram-se alguns entraves.

Nesse sentido, a proposta deste trabalho foi de revisar a implantação do projeto Sistema Público de Escrituração Digital - SPED e seus subprojetos, a fim de que se possa discutir as vantagens e desvantagens a partir da visão do profissional da Secretaria da Fazenda do Estado de Santa Catarina, responsável pela Escrituração Fiscal Digital. Com base no objetivo principal surgiu a pergunta de pesquisa: Quais as vantagens e desvantagens da implantação do SPED Fiscal a partir da literatura selecionada?

Para obter as respostas a essas indagações, foi elaborada entrevista com o responsável pela área na SEFAZ/SC, com perguntas abertas, tendo por base 0 referencial teórico que informa o tema. A entrevista foi dividida em duas partes: a primeira trata mais a respeito do projeto SPED em geral para um melhor conhecimento e aproximação do tema e a segunda trata mais específicamente da Escrituração Fiscal Digital, 
voltando-se ao tema de pesquisa.

Os resultados apontaram como principais dificuldades de implantação do SPED a preparação do pessoal, seguida pelo custo financeiro e as mudanças na estrutura da empresa.Existe também certa insegurança por parte dos profissionais quanto à correta aplicação dos procedimentos estabelecidos na legislação, em função das inúmeras exigências que 0 SPED traz. Para os respondentes, as modificações são inúmeras, exigindo cada dia mais dos profissionais contábeis. No entanto, relatam que aqueles profissionais que estão se adequando às novas exigências e que possuem domínio do assunto estão visivelmente sendo mais valorizados.

Toda essa busca por adequação, por parte do profissional da área contábil, para atender às exigências do SPED, teve como resultado direto apresentado pelos respondentes a melhoria na qualidade da informação, 0 ganho de produtividade e a agilidade nos processos.

Diante do apresentado anteriormente, 0 presente estudo responde aos objetivos estabelecidos no trabalho.

$\mathrm{Na}$ visão dos autores, o SPED traz uma postura do profissional de Contabilidade, o qual era visto por muitos como um profissional que exerce funções meramente fiscais. Com o SPED o trabalho intelectual, 0 conhecimento do contador sobrepõe-se ao operacional. Exige-se ainda que o profissional tenha visão gerencial, conhecimento em informática, habilidade de aprender, poder de feedback.

Para a execução da pesquisa foram identificadas limitações quanto a: realização de entrevistas com as pessoas responsáveis na Secretaria da Fazenda Estadual. Outra limitação ainda foi a escolha do método mais adequado aos propósitos da investigação, para a maior pertinência no andamento da entrevista e intimidade com o entrevistado.

Recomenda-se, para futuros trabalhos, quanto ao tema aqui abordado, a continuação deste estudo por meio da ampliação do número de respondentes, por entender que, dessa maneira, obterse-á um resultado mais confiável quanto à percepção dos responsáveis da Secretaria da Fazenda pelos subprojetos do SPED. Pode-se, ainda, aplicar o mesmo questionário a Estados diferentes, a fim de comparar os impactos do SPED em cada Estado.

\section{REFERÊNCIAS}

ALAVI, Maryam; CARLSON, Patrícia.A review of MIS research and disciplinary development.Journal of Management Information Systems. v. 8, n 4, 1992.

BAHIA, Álvaro Antônio. Segunda geração da Nota Fiscal Eletrônica começa neste semestre. 2009. Disponível em: <http://www.nike-consulting.com/site/index.ph p?option=com_content\&view=article\&catid=3\%3Anoticias\&id=58\%3Asegunda-gerac ao-da-nota-fiscal-eletronicacomeca-neste-semestre\&ltemid=71\&lang=br>. Acesso em: 30 de junho de 2010.

BISATO, Izaura Roberta; LINKE, Ivanete. Os novos procedimentos contábeis apresentados pelo sistema público de escrituração digital (SPED). Revista do Conselho Regional de Contabilidade do Paraná (CRC-PR), Curitiba, ano $33, n^{0} 151$, p. $5-19,2^{\circ}$ quadrimestre de 2008.

BOAL, Luiz; JUSKOW, Sergio. Os impactos da NF-e e do SPED para o Contabilista. Apostila PROJETO EDUCAÇÃO CONTINUADA - CRC. Maio 2009.

BORGES, Thiago. Nota fiscal eletrônica entra na segunda geração. Revista Exame. São Paulo, Editora Abril S.A., edição 950, 08/2009. Disponível em: <http://www. robertodiasduarte.com.br/nota-fiscal-eletronica-entra-na-segundageracao/>. Acesso em: 30 de junho de 2010.

BRASIL, Decreto $n^{0}$ 6.022, de 22 de janeiro de 2007. Institui o sistema público de escrituração digital - SPED. Disponível em: <www.planalto.gov.br/ccivil_03/_Atos 2007-2010/2007/Decreto/D6022.htm>. Acesso em: 09 de maio de 2010. 
BRASIL. Conselho Federal de Contabilidade. Profissionais e escritórios ativos nos conselhos regionais de contabilidade: abril 2010. Disponível em: <http://www.cfc.org. br/uparq/Ativos_201004.pdf>. Acesso em: 03 de junho de 2010.

BRASIL. Protocolo ICMS 42, de 3 de julho de 2009. Estabelece a obrigatoriedade da utilização da Nota Fiscal Eletrônica. Disponível em: <http://www.faze nda.gov.br/confaz/confaz/protocolos/icms/2009/pt042_09.htm>. Acesso em: 07 de dezembro de 2011.

CLETO, Nivaldo. Nota fiscal eletrônica (NF-e) - revolução digital no meio empresarial e contábil. Revista do Conselho Regional de Contabilidade do Paraná (CRC-PR), Curitiba, ano 31, nº 145, p. 4-6, $2^{\circ}$ quadrimestre de 2006.

CLETO, Nivaldo; OLIVEIRA, Fábio Rodrigues de. Manual de autenticação dos livros digitais: atualizado até 21 de maio de 2010. São Paulo: Fisco Soft, 2010. Disponível em: <http://www.fiscosoft.com.br/spedcontabil>. Acesso em: 12 de junho de 2010.

DUARTE, Roberto Dias. Vem aí a segunda geração da Nota Fiscal Eletrônica. 2009. Disponível em: <http://www.robertodiasduarte.com.br/vem-ai-a-segunda-gerac ao-da-nota-fiscal-eletronical>. Acesso em: 30 de junho de 2010.

FACCI, Nilton et al. Os riscos da sonegação fiscal para o profissional da Contabilidade. 2005. Disponível em: <www.fema.com.br/ danilo/pro/menu/.../artigo_sonegacao_fiscal.doc>. Acesso em: 06 de dezembro de 2011.

FARIA, Ana Cristina de et al. SPED - Sistema Público de Escrituração Digital: Percepção dos contribuintes em relação os impactos da adoção do SPED. In: CONGRESSO USP DE CONTROLADORIA E CONTABILIDADE, 10, 2010, São Paulo, Anais. São Paulo: 2010. p. 1-19.

FRANCISCO, Suzana; RONCHI, Suelen Haidar; MECHELN, Pedro José Von. Os impactos da implantação do sistema público de escrituração digital (SPED) na gestão das micro e pequenas empresas. In: CONGRESSO UFSC DE CONTROLADORIA E FINANÇAS \& INICIAÇÃO CIENTÍFICA EM CONTABILIDADE, 2, 2009, Florianópolis, Anais. Florianópolis: 2008. p. 1-14.

GIL, Antônio Carlos. Como elaborar projetos de pesquisa. 3 ed. São Paulo: Atlas, 1991. 176 p.

JORNAL NACIONAL. Brasil é bicampeão na burocracia dos impostos para as empresas. Edicão do dia 11/11/2011. Disponível em: <http://g1.globo.com/jornal-nacional/noticia/2011/11/brasil-e-bicampeao-na-burocraciados-impostos-para-empr esas.html>. Acesso em: 12 de novembro de 2011.

LONGARAY, André Andrade; BEUREN, Ilse Maria. Caracterização da pesquisa em contabilidade. In: BEUREN, Ilse Maria. Como elaborar trabalhos monográficos em contabilidade: teoria e prática. $3^{\mathrm{a}}$ ed. São Paulo: Atlas, 2006.

MAHLE, Marciane Maria; SANTANA, Alex Fabiano Bertollo. Sistema público de escrituração digital - SPED: um estudo nos escritórios de contabilidade no município de Pinhalzinho/SC. Revista Catarinense da Ciência Contábil (CRC-SC), Florianópolis, v.8, n² 23, p. 73-92, abr./jul. 2009.

MARTINS, Milca Schneider; LUCIANO, Edimara Mezzomo; TESTA, Mauricio Gregianin. Proposta de um framework para apoio à adoção da nota fiscal eletrônica. In: ENCONTRO DAANPAD, XXXII, 2008, Rio de Janeiro, Anais. Rio de Janeiro: 2008. p. 1-15.

OLIVEIRA, Wolney Resende de; MAIA, Diulie Fernandes. Nota fiscal eletrônica: projeto nacional e a iniciativa municipal de São Paulo - uma análise comparativa. In: CONGRESSO BRASILEIRO DE CONTABILIDADE, 18, 2008, Gramado, Anais... Gramado: 2008. p. 1-15. 
PEIXE, Blênio César Severo; FELSKY, Carlos Emílio. Compatibilizar as demonstrações contábeis de acordo com o modelo governamental - proposta de adaptação à escrituração contábil digital. In: CONGRESSO UFSC DE CONTROLADORIA E FINANÇAS \& INICIAÇÃO CIENTÍFICA EM CONTABILIDADE, 3, 2010, Florianópolis, Anais... Florianópolis: 2009. p. 1-13.

PEREIRA, Sidinei Aparecido et al. Governança eletrônica na administração pública: estudo de caso sobre a nota fiscal eletrônica - NF-e. In: CONGRESSO BRASILEIRO DE CONTABILIDADE, 18, 2008, Gramado, Anais... Gramado: 2008. p. 1-12.

POPE, Catherine; MAYS, Nick. Reaching the parts other methods cannot reach:an introduction to qualitative methods in health and health service research. British Medical Journal, n³11, 1995, p. 42-45.

RECEITA FEDERAL DO BRASIL. Portal da Nota Fiscal Eletrônica. Disponível em: <http://www.nfe.fazenda.gov.br/portal/>. Acesso em: 01 de julho de 2010.

Objetivos do Sistema Público de Escrituração Digital - SPED. Disponível em:<http://www1.receita.fazenda.gov.br/sobre-o-projeto/objetivos.htm>. Acesso em 10 de agosto de 2012.

RICHARDSON, Roberto Jarry. Pesquisa social: métodos e técnicas. $3^{a}$ edição. São Paulo: Atlas, 1999. 328 p.

SANTOS, Bianca dos; MÜLLER, Neri; CASAGRANDE, Maria Denize Henrique. NF-e - Nota Fiscal Eletrônica: Percepção dos contribuintes enquadrados na atividade de comércio atacadista de produtos alimentícios em geral, estabelecidos no município de Florianópolis. In: CONGRESSO UFSC DE CONTROLADORIA E FINANÇAS \& INICIAÇÃO CIENTÍFICA EM CONTABILIDADE, 4, 2011, Florianópolis, Anais... Florianópolis: 2011. p. 1-16.

SANTOS, Katia Gardenia dos. SPED - o enfoque na escrituração contábil digital. Revista do Conselho Regional de Contabilidade do Paraná (CRC-PR), Curitiba, ano 34, nº 154, p. 37-42, 2º quadrimestre de 2009.

SEBOLD, Márcia; PIONER, Lucas Mello; PIONER, João José Mello. Novos rumos na Contabilidade Pública brasileira: do governo eletrônico ao Sistema Público de Escrituração Digital - SPED. In: CONGRESSO UFSC DE CONTROLADORIA E FINANÇAS \& INICIAÇÃO CIENTÍFICA EM CONTABILIDADE, 4, 2011, Florianópolis, Anais... Florianópolis: 2011. p. 1-12

SEFAZ RS. Dúvidas / assuntos / a secretaria / apresentação. Disponível em: <http://www.sefaz.rs.gov.br/Site/MontaDuvidasTema.aspx?tema=A\%20Secretaria>. Acesso em: 12 de junho de 2010.

SILVA, Cristiane Francisca da.Percepções dos usuários dos sistemas contábeis nos escritórios de contabilidade confrontando com a visão do programador. 2003. 81 f. Monografia (Graduação em Ciências Contábeis) - Universidade do Vale do Itajaí - UNIVALI, Biguaçu.

VIEIRA, Valter Afonso. As tipologias, variações e características da pesquisa de Marketing. Revista da FAE. Curitiba, v.5, n.1, p.61-70, jan./abr. 2002. Disponível em:

<http://www.fae.edu/publicacoes/pdf/revista_da_fae/fae_v5_n1/as_tipologias_va riacoes_.pdf>.Acesso em: 12 de junho de 2010.

YOUNG, Lúcia Helena Briski. SPED: sistema público de escrituração digital. Curitiba: Editora Juruá, 2009. p.287 


\section{ENDEREÇO DOS AUTORES:}

\section{SÉRGIO MURILO PETRI}

Rua João Meirelles, 1179, Bloco 5, Apto 33

Abraão | Florianópolis/SC | CEP: 88.085-201

E-mail: sergio.petri@ufsc.br

\section{BÁRBARA HEIDRICH SEIBERT KOETTKER}

Travessa da Liberdade, 457, Casa 319

Campeche |Florianópolis/SC | Cep: 88063-210

E-mail: barbaraseibert@msn.com

\section{TATIANE MARQUES DE OLIVEIRA}

Rua Sady de Marco, 261-D, ap. 202, BL II. Jardim Itália, Chapecó, SC. CEP 89802-280

E-mail: tatianedemarques@gmail.com

\section{LUANA RAMOS FIGUEIREDO PETRI}

Rua João Meirelles, 1179, Bloco 5 Apto 33 Abraão | Florianópolis/SC | CEP: 88.085-201

E-mail: luanaramos@sc.senac.br

\section{MARIA DENIZE HENRIQUE CASAGRANDE}

Rua Araci Vaz Callado, 686, Apto 401

Estreito | Florianópolis/SC | CEP: 88070-750

E-mail: denize_casagrande@yahoo.com.br

Submissão em 13/06/2012

Revisão em 29/06/2012

Aceito em 03/12/2012 